\title{
Baseline analysis of productivity changes with and without considering carbon dioxide emissions in the major manufacturing sector of Indonesia
}

\author{
Erik Armundito ${ }^{1,2^{*}}$ (D) and Shinji Kaneko ${ }^{1}$
}

\author{
* Correspondence: \\ armundito@yahoo.com \\ ${ }^{1}$ Graduate School for International \\ Development and Cooperation \\ (IDEC), Hiroshima University, 1-5-1, \\ Kagamiyama, Higashi-hiroshima-shi, \\ Hiroshima-ken 739-8529, Japan \\ ${ }^{2}$ National Development Planning \\ Agency (BAPPENAS), J. Taman \\ Suropati No. 2, Jakarta Pusat, DKI \\ Jakarta 10310, Indonesia
}

\begin{abstract}
This paper provides empirical evidence of changes in the productivities of manufacturing firms in Indonesia over time, in the form of total factor productivity (TFP), from 1990 to 2010 with and without considering carbon dioxide $\left(\mathrm{CO}_{2}\right)$ emissions. Employing cleaned and balanced panel datasets for four periods, 1990-1995, 1998-2000, 2003-2006, and 2008-2010, the analysis enables an evaluation of the impact of implemented policies or economic circumstances during each period. The Malmquist productivity index is employed to estimate TFP without $\mathrm{CO}_{2}$ emissions over time, whereas the Malmquist-Luenberger productivity index is applied to estimate TFP with $\mathrm{CO}_{2}$ emissions over time. Furthermore, the influence of energy factors on environmental productivity is also investigated. The results show that on average, TFP with $\mathrm{CO}_{2}$ emissions over time has grown faster than TFP without $\mathrm{CO}_{2}$ emissions, particularly for periods 1,2 , and 4 . Technical progress is the basis of productivity growth after removing energy subsidies, and the change in environmental productivity is associated with the adjusted energy prices. Constructive policy designs can be derived from this paper that will enhance manufacturing sector performance after changes in the prices of oil commodities.
\end{abstract}

Keywords: Total factor productivity; Directional distance function; Malmquist-Luenberger productivity index; Manufacturing sector

JEL Classification: C61; D24; 047

\section{Background}

The abundance of fossil energy resources as well as a large population has been the foundation of development in Indonesia. However, since 2004, Indonesia has become a net oil-importing country if we consider the trade balance of both crude oil and petroleum commodities. In addition, as of 2013, Indonesia ranked as the 11th largest $\mathrm{CO}_{2}$ emitting country after Canada [1]. As a growing and developing country in Asia with a relatively large but young demographic structure, Indonesia will not only confront domestic policy challenges but will also begin to draw international attention after China and India in seeking a future development pathway that is less fossil energy resource dependent and that creates more job opportunities.

Although these challenges should be addressed by various sectors as declared by Indonesia's master plan of 2011, the manufacturing sector is one of the most important 
sectors due to its large potential for creating job opportunities. At the same time, there is concern regarding the increasing demand for energy generated by the economic development policy through further industrialization and development of the manufacturing sector. Currently, total final energy consumption (TFEC) in the manufacturing sector represents $27.4 \%$ of the TFEC of Indonesia in 2011, and this share has been growing steadily over the last two decades [2].

As the international oil price has increased since 2000 and has remained high compared to prices in the 1990s, the government of Indonesia as a net oil-importing country started to gradually remove subsidies for energy commodities starting in 2005. Consequently, the domestic price of oil commodities in Indonesia has been rising since this time, which has caused a significant financial burden for the manufacturing industry. Although economic instruments implemented within climate change mitigation policies such as a carbon tax have not yet been implemented in Indonesia, the recent rising price of domestic oil commodities can be seen as a quasi-carbon tax instrument because it has similar consequences. With these as background and motivation, this paper reports empirical evidence of changes in the total factor productivity (TFP) of manufacturing firms in Indonesia over time from 1990 to 2010 with and without considering $\mathrm{CO}_{2}$ emissions. The comparison of the TFP with and without considering $\mathrm{CO}_{2}$ emissions across different sectors of the manufacturing industry enables us to identify firm reactions to changes in the prices of oil commodities. It should be noted that although historical data for manufacturing firms in Indonesia are available from the datasets of annual manufacturing surveys conducted by the Indonesian Statistics Agency (BPS) for medium- and large-sized firms that employ at least 20 workers, the datasets contain inaccurate, incomplete, and erroneous data. Therefore, despite the availability of large sets of data, to the best of our knowledge, empirical studies of Indonesian manufacturing firms are limited.

To overcome this constraint, we first developed a cleaned panel dataset from the annual survey data of medium- and large-sized firms in the manufacturing sector of Indonesia between 1990 and 2010, which is used for the present analysis. Because the system of firm identity codes was changed between 2000 and 2001, it is impossible to construct continuous annual firm datasets between two periods, namely 1990-2000 and 2001-2010. In addition, we found that some of key variables such as capital stock and energy consumption, which are necessary for the present analysis, are completely missing in the survey data for 1996, 1997, 2001, 2002, and 2007. Therefore, the cleaned and balanced panel datasets are constructed for only four periods: 1990-1995, 19982000, 2003-2006, and 2008-2010. For these periods, the paper provides empirical results from the baseline analysis for productivity measurements.

The remainder of the paper is organized as follows. provides a brief description of the contextual background of the analysis and a literature review. Section 2 explains the methodological approach. Section 3 presents the empirical results and a discussion, followed by concluding remarks in Section 4 .

The state-led industrial policy strategy began in the 1970s in Indonesia during the Suharto regime, driven by a large windfall in government oil revenue from 1973 to 1980 through the development of state-owned firms. The government strictly protected the state-owned firms and other domestic producers from international competition by providing tariff and non-tariff barriers, raw material subsidies, and credit subsidies in addition 
to maintaining undervalued exchange rates $[3,4]$. Whereas the share of the manufacturing sector to GDP increased, empirical studies generally agreed that there was no gain and potentially negative TFP growth in the manufacturing sector in Indonesia during the period between 1975 and 1985 [5-7]. In 1986, the devaluation of the exchange rate of the rupiah against the US dollar triggered a shift in foreign direct investment (FDI) from the Asian newly industrialized economies to Indonesia, which promoted a labor-intensive manufacturing base in industries such as textiles, shoes, wood products, and processed food. As a result of an increasingly open economic policy, the share of manufacturing products has significantly expanded in terms of foreign exports since the middle of the 1980s. Furthermore, with the development of the machinery industry driven by FDI, the export of machinery products has also increased since the late 1980s and early 1990s. The shift to an FDI-led import substitution policy of industrialization has resulted in an increase in TFP for the manufacturing sector of Indonesia.

Table 1 summarizes the results of the selected literature measuring the TFP growth of the Indonesian manufacturing sector using firm-level data for the period between 1970 and 2000. Although specific periods and numbers are not exactly the same and comparable, general shifts in TFP growth before and after the middle of the 1980s are commonly and consistently reported. Moreover, TFP growth seems to have continued until 1997, at which point the Asian economic crisis hit the Indonesian economy. Suharto's relinquishing presidential office in 1998 evidences the seriousness of the adverse effects from the Asian financial crisis on the Indonesian economy, and this crisis also caused significant turbulence and confusion in measurements of TFP growth.

Table 1 TFP growth measurements using firm-level data for the Indonesian manufacturing sector

\begin{tabular}{|c|c|c|c|}
\hline Authors & Methods & Periods & Annual TFP growth (\%) \\
\hline \multirow[t]{5}{*}{ 1. Timmer [5] } & \multirow[t]{5}{*}{ Growth accounting method } & 1975-1981 & 1.1 \\
\hline & & 1982-1985 & 0.1 \\
\hline & & 1986-1990 & 7.9 \\
\hline & & 1991-1995 & 2.1 \\
\hline & & 1975-1995 & 2.8 \\
\hline \multirow[t]{5}{*}{ 2. Aswicahyono and Hill [6] } & \multirow[t]{5}{*}{ Growth accounting method } & 1976-1980 & 1.1 \\
\hline & & $1981-1983$ & -4.9 \\
\hline & & 1984-1988 & 5.5 \\
\hline & & 1989-1993 & 6.0 \\
\hline & & 1975-1993 & 2.7 \\
\hline \multirow[t]{5}{*}{ 3. Vial [7] } & \multirow[t]{5}{*}{ Cobb-Douglas production function } & 1976-1980 & 1.5 \\
\hline & & $1981-1983$ & -0.1 \\
\hline & & 1984-1988 & 5.1 \\
\hline & & 1989-1993 & 8.0 \\
\hline & & 1976-1996 & 3.5 \\
\hline \multirow[t]{4}{*}{ 4. Ikhsan-Modjo [34] } & \multirow[t]{4}{*}{ Stochastic production frontier } & 1988-1992 & 2.7 \\
\hline & & 1993-1996 & 2.9 \\
\hline & & 1997-2000 & -0.6 \\
\hline & & $1988-2000$ & 1.6 \\
\hline
\end{tabular}

TFP total factor productivity 
As mentioned earlier, the datasets used in our analysis have several breaks, and the period before and after the Asian financial crisis is one of these breaks. Table 2 provides a summary of the key variables in the four analyzed periods to describe the contextual background of the present analysis.

Period 1 from 1990 to 1995, which is the longest among the four analyzed periods in the paper, exhibited the highest average GDP growth rate at $7.9 \%$, and the growth rate of the manufacturing sector during this period was also the highest. Consequently, the share of the manufacturing sector to GDP increased from 21.6 to $24.5 \%$, and the share in total merchandise exports also increased from 35.5 to $50.6 \%$. Furthermore, the share of high-technology exports to manufactured exports expanded substantially from 1.6 to $7.3 \%$. In contrast, the growth rate of total final energy consumption (TFEC) for Indonesia and the growth rate of the manufacturing sector grew less quickly than that for production, resulting in an elasticity of TFEC to GDP of 0.57 and 0.75 , respectively. Although net crude oil exports and the share of fuel exports to merchandise exports have been declining during the period, trade surpluses of more than 30 million TOE of crude oil were maintained. Overall, the last phase of the Suharto regime can be summarized as a time when the productivity and energy efficiency of the manufacturing sector was improved through an export-led industrialization policy.

Period 2 from 1998 to 2000 is characterized as an immediate post-economic crisis period and marks the beginning of democratic reforms after the Suharto regime. Per capita GDP in constant US dollars at 2005 prices moved to an even lower range compared to 1995, and the average GDP growth rate was only $2.8 \%$ during the period. However, the manufacturing sector performed relatively better despite the negative effects of the financial crisis. The share of the manufacturing sector to GDP slightly expanded from 26.0 to $27.1 \%$ and that of exports to merchandise increased from 45.0 to $57.1 \%$. At the same time, the share of high-technology exports to manufactured exports also continued to increase from 10.4 to $16.4 \%$. However, energy consumption in Indonesia sharply increased during this time, and the elasticity of TFEC to GDP was 2.07 , whereas the elasticity of the manufacturing sector was 1.25 . Net crude oil exports started to decline from 27.3 to 17.4 million TOE, and the net export of oil products turned negative during this period.

Period 3 between 2003 and 2006 covers a politically significant transitional moment when President Yudoyono became the first president of the country elected by a direct presidential election in 2004. Immediately after electing a new president, the Sumatra-Andaman earthquake and tsunami hit the country. The period first experienced a transition from positive to negative net oil exports considering both crude oil and oil commodities. Coincidentally, unprecedented and continuously soaring international oil prices finally forced the government of Indonesia to begin removing subsidies for oil commodities twice in 1 year in March and October 2005, doubling the prices for most oil commodities in the domestic market. Under these conditions, the manufacturing sector grew annually by $5.2 \%$ on average, which was slightly lower than GDP growth. Meanwhile, the share of manufactured exports to merchandise exports dropped from 52.1 to $44.7 \%$, and the share of hightechnology exports to manufactured exports also shrank from 14.8 to $13.5 \%$. The energy intensity of the country as measured by the ratio of TFEC to GDP greatly improved, while the energy intensity of the manufacturing sector worsened. It is expected that manufacturing firms faced a significant increase in energy costs. 
Table 2 Summary of key variables for four analytical periods

\begin{tabular}{|c|c|c|c|c|c|c|c|c|c|c|}
\hline \multirow[b]{2}{*}{ Variables } & \multirow[b]{2}{*}{ Unit } & \multirow[b]{2}{*}{ Source } & \multicolumn{2}{|c|}{ Period 1 (6 years) } & \multicolumn{2}{|c|}{ Period 2 (3 years) } & \multicolumn{2}{|c|}{ Period 3 (4 years) } & \multicolumn{2}{|c|}{ Period 4 (3 years) } \\
\hline & & & 1990 & 1995 & 1998 & 2000 & 2003 & 2006 & 2008 & 2010 \\
\hline Per capita GDP & USD at 2005 price & a & 840.2 & 1129.1 & 1057.1 & 1086.1 & 1180.5 & 1324.5 & 1451.6 & 1570.2 \\
\hline GDP growth rate & $\%$ & a & 7.9 & & 2.8 & & 5.4 & & 5.4 & \\
\hline Growth rate of value added in manufacturing sector & & a & 10.6 & & 4.9 & & 5.2 & & 3.5 & \\
\hline Share of manufacturing sector to GDP & $\%$ & a & 21.6 & 24.5 & 26.0 & 27.1 & 27.3 & 27.2 & 26.1 & 25.2 \\
\hline Share of manufactures exports to merchandise exports & $\%$ & a & 35.5 & 50.6 & 45.0 & 57.1 & 52.1 & 44.7 & 38.8 & 37.5 \\
\hline Share of high-technology exports to manufactured exports & $\%$ & a & 1.6 & 7.3 & 10.4 & 16.4 & 14.8 & 13.5 & 10.9 & 9.8 \\
\hline Total final energy consumption (TFEC) & 1000 TOE & $b$ & 79,817 & 99,513 & 107,332 & 120,323 & 128,043 & 139,427 & 139,686 & 156,113 \\
\hline Growth rate of TFEC & $\%$ & $b$ & 4.5 & & 5.9 & & 2.9 & & 5.7 & \\
\hline Elasticity of total TFEC to GDP & - & $\mathrm{a} / \mathrm{b}$ & 0.57 & & 2.07 & & 0.53 & & 1.05 & \\
\hline Energy intensity (TFEC/GDP) & TOE/USD at 2005 price & $\mathrm{a} / \mathrm{b}$ & 531.8 & 454.1 & 500.2 & 530.2 & 497.2 & 462.3 & 410.8 & 413.1 \\
\hline TFEC in manufacturing sector & 1000 TOE & $b$ & 17,805 & 26,087 & 26,914 & 30,333 & 33,548 & 43,820 & 39,971 & 45,264 \\
\hline Growth rate of TFEC in manufacturing sector & $\%$ & $b$ & 7.9 & & 6.2 & & 9.3 & & 6.4 & \\
\hline Elasticity of TFEC to GDP in manufacturing sector & - & $a / b$ & 0.75 & & 1.25 & & 1.80 & & 1.85 & \\
\hline Energy intensity of manufacturing sector & TOE/USD at 2005 price & $a / b$ & 548.8 & 486.3 & 482.3 & 493.5 & 476.5 & 534.8 & 449.6 & 475.6 \\
\hline Net export of crude oil & 1000 TOE & $b$ & 32,328 & 30,744 & 27,349 & 17,390 & 7043 & $(2860)$ & 1350 & $(2171)$ \\
\hline Net export of oil products & 1000 TOE & $b$ & 8054 & 2675 & 1529 & $(4181)$ & $(6896)$ & $(11,598)$ & $(15,860)$ & $(20,722)$ \\
\hline Share of fuel exports to merchandise exports & $\%$ & a & 44.0 & 25.4 & 19.1 & 25.4 & 25.8 & 27.2 & 29.1 & 29.7 \\
\hline
\end{tabular}

Note: a) World Development Indicators 2014, b) IEA Energy Balance Tables for Non-OECD Countries, 2013

GDP gross domestic product, TOE tons of oil equivalent, USD US dollar 
Period 4 from 2008 to 2010 was in the middle of the 10-year presidency of Yudoyono and of the global financial crisis triggered by the subprime mortgage crisis and the bankruptcy of Lehman Brothers in 2008. The adverse shock caused in Indonesia by the global financial crisis was relatively small, and the average GDP growth rate in period 4 was maintained, staying as high as that of period 3. However, the growth rate of the manufacturing sector slowed and the shares of the manufacturing sector to GDP, manufactured products to merchandise exports, and high-technology products to manufactured products all shrank. At the same time, dependency on imported oil commodities increased remarkably, whereas the average growth rate of TFEC in the manufacturing sector was $6.4 \%$, which is much higher than production growth, resulting in an elasticity of 1.85. Amid such circumstances, the overall energy intensity of manufacturing firms did not improve. Further subsidy removal was implemented in 2008, and it is likely that the additional burden put a strain on manufacturing firms.

A number of studies have attempted to analyze changes in productivity addressing multiple outputs, including both desirable and undesirable outputs. Data envelopment analysis (DEA) is one approach commonly employed to measure productive efficiency and is known as a non-parametric frontier approach [8]. DEA develops a nonparametric envelopment frontier encompassing all sample data as observed points lying on or below the frontier. The points on the production frontier are considered to be efficient decision-making units (DMUs), and the points below the production frontier are regarded as inefficient DMUs. The efficiency of each observation is measured by calculating the distance between the observed level of production and the production frontier as solutions of a linear programming problem. However, the DEA method does not evaluate the shift in the frontier over time; instead DEA only estimates the performance of DMUs in reference to the best practice frontier in a given year. The Malmquist productivity index is then introduced by adjusting the DEA application for multiyear observations alternately between $t$ and $t+1$ to account for a shift in the frontier and to allow the measurement of changes in productive efficiency over time. The index measuring change in productive efficiency is then regarded as representing TFP growth, which can be further decomposed into efficiency change (catch-up) and technical progress (frontier-shift).

Several ideas and methods have been proposed to incorporate undesirable outputs into DEA approaches while assuming asymmetrical treatments of disposability between desirable outputs and undesirable outputs when production possibilities are defined [9]. An efficiency improvement strategy for inefficient DMUs is developed by holding one or two inputs, desirable outputs or undesirable outputs constant. For example, input orientation refers to a strategy that considers how much inputs can be reduced while holding both desirable and undesirable outputs unchanged (i.e., [10]). Some others suggest a bads orientation strategy, which considers how bads can be reduced while holding inputs and desirable outputs unchanged (i.e., [11]). Tyteca [11] also considers the third strategy, which examines how much bads and inputs can be reduced while holding desirable outputs unchanged. The other recent strategy to incorporate undesirable outputs is to consider the proportional reduction in inputs and undesirable outputs and the proportional increase in desirable outputs [12]. Based on the earlier method of simultaneous change in desirable outputs and undesirable outputs following a hyperbolic function where fixed inputs are assumed, Chung et al. [13] proposed an 
application of a directional distance function as well as a productivity index known as the Malmquist-Luenberger productivity index. The directional distance function (DDF) defines a strategy in which desirable and undesirable outputs are simultaneously changed. While the efficiency measurement with a DDF model in a single year is measured as the Luenberger productivity index, an alternate application of the DDF model between $t$ and $t+1$ to measure the Luenberger productivity index in such a way that a Malmquist productivity index is constructed can generate the Malmquist-Luenberger productivity index. Therefore, the Malmquist-Luenberger productivity index can be further decomposed into efficiency change (catch-up) and technical progress (frontier-shift).

Since Chung et al. [13] reported empirical results for Swedish firms in the paper and pulp industry using the directional distance function to develop the MalmquistLuenberger productivity index, the Malmquist-Luenberger productivity index has been widely used in various studies at different levels from micro (firm-level data), to industry (sector-level data), to macro (province, national, and regional-level data) for evaluating productivity changes considering undesirable outputs. Färe et al. [14] employ the Malmquist-Luenberger productivity index to study the US manufacturing sector from 1974 to 1986 and observed that average annual productivity growth was $3.6 \%$ when both desirable and undesirable outputs were considered, whereas it was $1.7 \%$ when undesirable outputs were ignored. A comparable finding was presented by [15], who employed a similar approach to estimate productivity growth for six US chemical industries for the period 1988 to 1993; they concluded that environmental protection measures did not reduce productivity growth. Several other studies, including $\mathrm{He}$ et al. [16] and Piot-Lepetit and Moing [17] have focused on micro-level issues, while Kumar [18], Oh [19], and Zhang et al. [20] focused on macro-level issues using stateand regional-level data. Furthermore, the Malmquist-Luenberger productivity index has also been applied to industrial-level issues by Boyd et al. [21], Heng et al. [22], and Krautzberger and Wetzel [23].

TFP growth might be greater or smaller when undesirable outputs are considered compared to TFP measurement without considering undesirable outputs. Table 3 compiles several studies that analyze and examine TFP growth using the MalmquistLuenberger productivity index with various topics, variables, and time periods. The results are discussed based on environmental regulation being the key determinant of the difference in productivity measurements with and without undesirable outputs. Chung et al. [13], Kumar [18], and He et al. [16] confirmed that TFP growth is higher when undesirable outputs are considered under stringent environmental regulations. However, these findings contrast with Zhang et al. [20], who analyzed TFP growth in China's 30 provincial regions, implying that environmental regulations are not very stringent or not strictly enforced.

Further indexing of TFP is proposed by Färe et al. [10] to elucidate the net contribution of environmental factors to productivity growth. Following this concept, Managi and Jena [24] estimate the ratio of TFP considering CO2 emissions to TFP without considering $\mathrm{CO} 2$ emissions as an environmental productivity measurement, which is referred to as the TFP environment. An increase in the TFP environment is considered to represent a positive achievement of proactive environmental measures or how well environmentally friendly technologies and managements are utilized [25]. 
Table 3 Selected studies using the Malmquist-Luenberger productivity index to analyze TFP growth

\begin{tabular}{|c|c|c|c|c|c|}
\hline \multirow[t]{2}{*}{ Authors } & \multirow[t]{2}{*}{ Topics } & \multirow[b]{2}{*}{ Unit of analysis } & \multirow[b]{2}{*}{ Period } & \multicolumn{2}{|l|}{ TFP growth } \\
\hline & & & & Without undesirable output (\%) & With undesirable output (\%) \\
\hline \multirow[t]{4}{*}{ 1. Chung et al. [13] } & Swedish pulp and paper industry: & Firm & $1986-1990$ & -0.3 & 3.9 \\
\hline & Inputs: labor, wood fiber, energy, capital & & & & \\
\hline & Desirable outputs: pulp & & & & \\
\hline & Undesirable outputs: BOD, COD, and SS & & & & \\
\hline \multirow[t]{4}{*}{ 2. Färe et al. [14] } & US State manufacturing air pollution emission: & Industry & 1974-1986 & 16.9 & 36.3 \\
\hline & Inputs: employees, capital & & & & \\
\hline & Desirable output: Gross State Product & & & & \\
\hline & Undesirable outputs: SOx, CO & & & & \\
\hline \multirow[t]{4}{*}{ 3. Kumar [18] } & 41 developed and developing countries: & Country & 1971-1992 & -0.002 & 0.02 \\
\hline & Inputs: labor, capital, energy consumption & & & & \\
\hline & Desirable output: GDP & & & & \\
\hline & Undesirable output: $\mathrm{CO}_{2}$ & & & & \\
\hline \multirow[t]{4}{*}{ 4. Zhang et al. [20] } & China's 30 provincial regions: & Province & 1989-2008 & 4.84 & 2.46 \\
\hline & Inputs: labor, capital & & & & \\
\hline & Desirable output: GDP & & & & \\
\hline & Undesirable output: $\mathrm{SO}_{2}$ & & & & \\
\hline \multirow[t]{4}{*}{ 5. He et al. [16] } & China's iron and steel industry: & Firm & $2006-2008$ & 19.2 & 19.8 \\
\hline & Inputs: net fixed assets, employees, energy & & & & \\
\hline & Desirable output: value added & & & & \\
\hline & Undesirable output: waste water, waste gas, solid waste & & & & \\
\hline
\end{tabular}

TFP total factor productivity, GDP gross domestic product, BOD biochemical oxygen demand, COD chemical oxygen demand, SS suspended solids, SOx sulphur oxide 


\section{Methods}

The Malmquist-Luenberger productivity index is applied to estimate productivity change over time considering $\mathrm{CO}_{2}$ emissions in manufacturing firms. Because no definite climate change mitigation policies such as carbon regulations have been imposed in Indonesia, an assumption must be made considering the disposability of $\mathrm{CO}_{2}$ emissions as undesirable outputs and not a free activity. The productivity without considering $\mathrm{CO}_{2}$ emissions is also calculated using the Malmquist productivity index. The comparison of the productivity change over time with and without considering $\mathrm{CO}_{2}$ emissions will define the TFP environment. The sequential steps in developing the approaches are described in this section.

\subsection{Modeling technology outputs}

Let us consider a production process that uses a vector of input $\mathrm{x} \in \mathfrak{R}_{+}^{\mathrm{N}}$ to produce a vector of desirable output and a vector of undesirable output, which are denoted as $y \in$ $\mathfrak{R}_{+}^{\mathrm{M}}$ and $\mathrm{b} \in \mathfrak{R}_{+}^{\mathrm{I}}$, respectively. The relationship between input and output is represented by the technology of its output set:

$$
P(x)=\{(y, b): x \text { can produce }(y, b)\}, x \in \mathfrak{R}_{+}^{N}
$$

The output set is assumed to have the following properties:

a. The first assumption is null-jointness, which implies that a positive amount of desirable output cannot be produced without producing an undesirable output:

$(y, b) \in P(x)$ and $b=0$, then $y=0$

b. The second assumption is referred to as the weak disposability of desirable and undesirable outputs:

$(y, b) \in P(x)$ and $0 \leq \theta \leq 1$, then $\theta(\mathrm{y}, \mathrm{b}) \in P(x)$

This assumption indicates that it is not possible to reduce undesirable outputs without reducing desirable outputs. When firms face an environmental regulation, the disposal of undesirable outputs may not be free.

c. The third assumption is known as the strong disposability of desirable outputs:

$$
(y, b) \in P(x) \text { and } y^{\prime} \leq y \text {, then }\left(y^{\prime}, \mathrm{b}\right) \in P(x) .
$$

This assumption suggests that it is possible to reduce desirable outputs without reducing undesirable outputs.

To satisfy the above conditions, following Färe et al. [26], a data envelopment analysis (DEA) model can be formulated. It is assumed that for each time period $t=1, \ldots, T$, there are $k=1, \ldots, K$ observations for inputs and outputs $\left(x^{k, t}, y^{k, t}, b^{k, t}\right)$. By employing DEA and these data, an output set can be constructed that satisfies the above three properties: 


$$
\begin{array}{lc}
P^{t}\left(x^{t}\right)=\left\{\left(y^{t}, b^{t}\right):\right. & \sum_{k=1}^{K} z_{k}^{t} x_{k n}^{t} \leq x_{n}^{t} \\
\sum_{k=1}^{K} z_{k}^{t} y_{k m}^{t} \geq y_{m}^{t} & m=1, \ldots, M \\
\sum_{k=1}^{K} z_{k}^{t} b_{k i}^{t}=b_{i}^{t} & i=1, \ldots, N \\
z_{k}^{t} \geq 0 & k=1, \ldots, K\}
\end{array}
$$

where $z_{k}^{t}$ are non-negative weights assigned to each observation in constructing the production possibility frontier. This output set implies that the production technology exhibits constant returns to scale. Moreover, to integrate the null-jointness of outputs, the following requirements are imposed on the DEA model:

$$
\begin{array}{ll}
\sum_{k=1}^{K} b_{k i}^{t}>0 & i=1, \ldots, I \\
\sum_{i=1}^{I} b_{k i}^{t}>0 & k=1, \ldots, K
\end{array}
$$

These requirements imply that every undesirable output is produced by some firm $k$ and that every firm $k$ produces at least one undesirable output.

The distance functions for each observation in the Malmquist index are calculated as the solutions to a linear programming problem. For example, for k',

$$
\begin{array}{lr}
\left(D_{0}^{t}\left(x^{t k^{\prime}}, y^{t k^{\prime}}, b^{t k^{\prime}} ; y^{t k^{\prime}}\right)\right)^{-1}=\max \theta, \\
\text { s.t. } \sum_{k=1}^{K} z_{k^{t} x^{\prime} \leq x_{k^{\prime} n}^{t}}^{t} & n=1, \ldots, N \\
\sum_{k=1}^{K} z_{k}^{t} y_{k^{\prime} m}^{t} \geq \theta y_{k^{\prime} m}^{t} & m=1, \ldots, M \\
\sum_{k=1}^{K} z_{k}^{t} b_{k^{\prime} i}^{t}=\theta b_{k^{\prime} i}^{t} & i=1, \ldots, I \\
z_{k}^{t} \geq 0 & k=1, \ldots, K
\end{array}
$$

\subsection{Directional distance function}

The directional distance function allows a firm to increase the production of desirable outputs and simultaneously decrease the production of undesirable outputs with a given number of inputs, formally defined as

$$
\underset{0}{\vec{D}}\left(x, y, b ; 0, g_{y},-g_{b}\right)=\sup \{\beta:(y+\beta g, b-\beta g) \in P(x-0)\} .
$$

where $g$ is the vector of directions in which both outputs can be scaled. Following Chung et al. [13], the direction applied is $g=\left(0, g_{y},-g_{b}\right)$, which implies that desirable outputs are increased, undesirable outputs are decreased, and inputs do not change. 
Following Mandal and Madheswaran [27], Fig. 1 illustrates the difference between the output distance function and the directional distance function. Suppose that $\mathrm{Oy}_{3} R S T b$ is output set $P^{S}(x)$ under unregulated technology and does not satisfy the null-jointness assumption while OERSTb is output set $P^{W}(x)$ under regulated technology and does satisfy the null-jointness assumption. The direction vector is defined as $g=(0, y,-b)$. The output distance function scales point $\mathrm{A}$ to point $\mathrm{R}$ on the boundary based on an output vector, indicating that desirable outputs increase from $y_{1}$ to $y_{3}$. In contrast, the directional distance function scales point $\mathrm{A}$ to point $\mathrm{A}^{\prime}$ on the boundary in the direction of increasing desirable outputs from $y_{1}$ to $y_{2}$ and decreasing undesirable outputs from $b_{2}$ to $b_{1}$. At point $A^{\prime}$, the output vector is $\left(y+\beta^{*} g_{y}, b-\beta^{*} g_{b}\right)$, where $\beta^{*}=\vec{D}$ $\left(x, y, b ; 0, g_{y}-g_{b}\right)$, with $\beta^{*} g_{y}$ being added to the desirable outputs and $\beta^{*} g_{b}$ being subtracted from the undesirable outputs.

\subsection{The Malmquist-Luenberger productivity index}

To define the Malmquist-Luenberger productivity index, directional distance functions are used with the direction of a vector as $g=(0, y,-b)$ and the technology of periods $t$ and $t+1$ as the reference technologies. Following Chung et al. [13], the index between periods $t$ and $t+1$ is expressed as:

$$
\mathrm{ML}_{t}^{t+1}=\left(\mathrm{ML}^{t} \times \mathrm{ML}^{t+1}\right)^{1 / 2}
$$

where $\mathrm{ML}^{t}$ and $\mathrm{ML}^{t+1}$ are the Malmquist-Luenberger productivity indices with the technology of periods $t$ and $t+1$ as the reference technologies, respectively. Both indices can be described as follows:

$$
\mathrm{ML}^{t}=\frac{\left[1+\underset{0}{\vec{D}} t\left(x^{t}, y^{t}, b^{t} ; y^{t},-b^{t}\right)\right]}{\left[1+\underset{0}{\vec{D}} t\left(x^{t+1}, y^{t+1}, b^{t+1} ; y^{t+1},-b^{t+1}\right)\right]}
$$

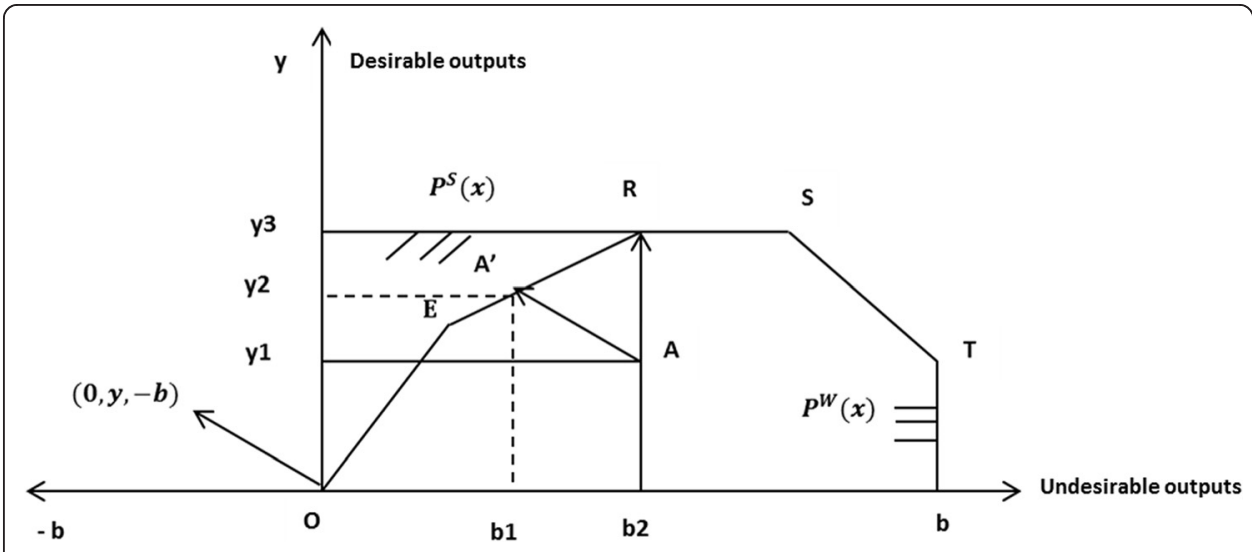

Fig. 1 Output distance function and directional distance function 


$$
\mathrm{ML}^{t+1}=\frac{\left[1+\underset{0}{\vec{D}} t+1\left(x^{t}, y^{t}, b^{t} ; y^{t},-b^{t}\right)\right]}{\left[1+\underset{0}{\vec{D}} t+1\left(x^{t+1}, y^{t+1}, b^{t+1} ; y^{t+1},-b^{t+1}\right)\right]}
$$

The Malmquist-Luenberger productivity index can be decomposed into an index of efficiency change (MLEFFCH) and an index of technological progress (MLTECH)

$$
\mathrm{ML}_{t}^{t+1}=\mathrm{MLEFFCH}_{t}^{t+1} \times \mathrm{MLTECH}_{t}^{t+1}
$$

where

$$
\operatorname{MLEFFCH}_{t}^{t+1}=\frac{\left[1+\underset{0}{\vec{D}} t\left(x^{t}, y^{t}, b^{t} ; y^{t},-b^{t}\right)\right]}{\left[1+\underset{0}{\vec{D}} t+1\left(x^{t+1}, y^{t+1}, b^{t+1} ; y^{t+1},-b^{t+1}\right)\right]}
$$

and

$\operatorname{MLTECH}_{t}^{t+1}=\left\{\frac{\left[1+\underset{0}{\vec{D}} t+1\left(x^{t}, y^{t}, b^{t} ; y^{t},-b^{t}\right)\right]\left[1+\underset{0}{\vec{D}} t+1\left(x^{t+1}, y^{t+1}, b^{t+1} ; y^{t+1},-b^{t+1}\right)\right]}{\left[1+\underset{0}{\vec{D}} t\left(x^{t}, y^{t}, b^{t} ; y^{t},-b^{t}\right)\right]\left[1+\underset{0}{\vec{D}} t\left(x^{t+1}, y^{t+1}, b^{t+1} ; y^{t+1},-b^{t+1}\right)\right]}\right\}^{1 / 2}$

Values greater than one for $\mathrm{ML}_{t}^{t+1}, \mathrm{EFFCH}_{t}^{t+1}$ and $\mathrm{TECH}_{t}^{t+1}$ indicate improvements in productivity, efficiency, and technology, respectively, while values less than one indicate declining productivity, efficiency, and technology. More specifically, the improvement of $\mathrm{EFFCH}_{t}^{t+1}$ from Equation 14 implies that the firm is closer to the frontier in period $t+1$ than it was in period $t$ as measured in terms of a proportional increase in the desirable outputs and a decrease in the undesirable outputs. The improvement of $\mathrm{TECH}_{t}^{t+1}$ from Equation 15 suggests that a firm shifts along the frontier in a direction that produces more desirable outputs and fewer undesirable outputs.

Linear programming (LP) is used to compute directional distance functions. Four LPs must be solved for each observation. Two LPs use the observations and technologies for period $t$ or $t+1$, and two LPs use mixed period technologies calculated from period $\mathrm{t}$ with the observations of $t+1$ and from period $t+1$ with the observations of $t$. The directional distance function for observation $k$ in period $t$ using period $t$ technology can be solved using Equation 16. For observation $k$ in period $t+1$ using period $t+1$ technology, the time superscript $t$ in Equation 16 for both sides must be changed to $t+1$.

$$
\begin{array}{lc}
\underset{0}{D} t\left(x^{t}, y^{t}, \quad b^{t} ; y^{t},-b^{t}\right)=\max , \\
\text { s.t. } \sum_{k=1}^{K} z_{k}^{t} x_{k n}^{t} \leq x_{k^{\prime} n}^{t} & n=1, \ldots, N \\
\sum_{k=1}^{K} z_{k}^{t} y_{k m}^{t} \geq(1+\beta) y_{k^{\prime} m}^{t} & m=1, \ldots, M \\
\sum_{k=1}^{K} z_{k}^{t} b_{k i}^{t}=(1-\beta) b_{k^{\prime} i}^{t} & i=1, \ldots, I
\end{array}
$$




$$
z_{k}^{t} \geq 0 \quad k=1, \ldots ., K
$$

Similarly, for mixed periods, the directional distance function for observation $k$ in period $t$ using period $t+1$ technology can be solved using Equation 21. For observation $k$ in period $t+1$ using period $t$ technology, the time superscripts on the left-hand side of the constraints in Equation 26 are $t+1$ and vice versa: in period $t$ using period $t+1$ technology, the time superscripts on the right-hand side of the constraints are $t$.

$$
\begin{array}{lr}
\underset{0}{D} t\left(x^{k^{\prime} t+1}, y^{k^{\prime} t+1}, \quad b^{k^{\prime} t+1} ; y^{k^{\prime} t+1},-b^{k^{\prime} t+1}\right)=\max , \\
\text { s.t. } \sum_{k=1}^{K} z_{k^{t} x_{k n}^{t} \leq x_{k^{\prime} n}^{t+1}} & n=1, \ldots, N \\
\sum_{k=1}^{K} z_{k}^{t} y_{k m}^{t} \geq(1+\beta) y_{k^{\prime} m}^{t+1}, & m=1, \ldots, M \\
\sum_{k=1}^{K} z_{k}^{t} b_{k i}^{t}=(1-\beta) b_{k^{\prime} i}^{t+1}, & i=1, \ldots, I \\
z_{k}^{t} \geq 0 & k=1, \ldots, K
\end{array}
$$

The Malmquist productivity index is constructed in a similar way to the MalmquistLuenberger productivity index. The Malmquist productivity index can also be decomposed into two components: the first component $\mathrm{MEFFCH}$ measures the efficiency change between the two periods and the second component MTECH measures the technical change between the two periods.

$$
\mathrm{M}_{t}^{t+1}=\mathrm{MEFFCH}_{t}^{t+1} \times \mathrm{MTECH}_{t}^{t+1}
$$

where

$$
\operatorname{MEFFCH}_{t}^{t+1}=\frac{\left[D_{0}^{t}\left(x^{t}, y^{t}, b^{t} ; y^{t}\right)\right]}{\left[D_{0}^{t+1}\left(x^{t+1}, y^{t+1}, b^{t+1} ; y^{t+1}\right)\right]}
$$

and

$$
\operatorname{MTECH}_{t}^{t+1}=\left\{\frac{\left[D_{0}^{t+1}\left(x^{t}, y^{t}, b^{t} ; y^{t}\right)\right]\left[D_{0}^{t+1}\left(x^{t+1}, y^{t+1}, b^{t+1} ; y^{t+1}\right)\right]}{\left[D_{0}^{t}\left(x^{t}, y^{t}, b^{t} ; y^{t}\right)\right]\left[D_{0}^{t}\left(x^{t+1}, y^{t+1}, b^{t+1} ; y^{t+1}\right)\right]}\right\}^{1 / 2}
$$

\subsection{Determinant of environmental productivity}

The relationship between TFP environment change over time and changes in energy factors is analyzed to investigate the determinant of environmental productivity. As economic growth and the manufacturing sector are highly dependent on energy, the increase of oil prices has affected the economic growth of many emerging economies. The number of studies investigating the impact of oil price changes on economic activities has significantly grown since Hamilton [28] suggested a negative relationship between oil price changes and economic activities. This finding is also supported by Hooker [29], who argued that oil price changes significantly caused US inflation and productivity, and Hamilton [30], who analyzed the impact of oil price changes on US macroeconomic components during 2007 to 2008. In particular, Aye et al. [31] analyzed 
the effect of oil price changes on manufacturing production in South Africa. The analysis results suggested that oil price changes significantly and negatively impact South Africa's manufacturing production and that manufacturing production responded asymmetrically to increasing and decreasing oil price changes. Unexpected increases in oil prices directly trigger a production cost increase and hence lead to declining productivity. If high oil costs persist, energy shifts or energy savings might be required for long-term productivity growth.

The approach applied to evaluate the influence of energy factors on environmental productivity over time in Indonesia's manufacturing sector is to conduct a simple regression analysis using panel data.

Formally, the mathematical model can be defined as:

$$
Y_{i(t, t+1)}=f\left(X_{i, t}\right)=\beta+\sum \beta_{i} X_{i t}+\mu_{i t}
$$

where $Y_{i(t, t+1)}$ and $X_{i t}$ are the environmental productivity change over time of the $i$ th firm at $t$ to $t+1$ periods and the determinants (the explanatory variables) of the $i$ th firm at $t$ period, respectively; $\beta s$ are parameters to be estimated; and $\mu$ is the error term. The explanatory variables are the average domestic fuel price (Fuelprice), the average electricity price (Elecprice), energy dependency (Energydep), and a sectoral dummy variable (dsec). Energy dependency is defined as the ratio of total energy expenditures to the total intermediate input expenditures. The sectoral dummy (dsec) is used for simplification purposes to capture the effect of sectoral differences and has the value of one for a firm included in the particular sector classification, and zero otherwise. The classification for sectoral dummies is based on sectors with similar characteristics in their production process: (i) dsec $1=$ food, beverage, and tobacco group, (ii) dsec $2=$ textile and leather group, (iii) dsec $3=$ wood, paper, printing, and furniture group, (iv) dsec 4 = chemical, rubber, and plastic group, (v) dsec $5=$ electrical, machinery, and transport group, and (vi) dsec $6=$ metal and mineral group. The metal and mineral group sector is the basis of the sectoral dummy.

\subsection{Data and variables construction}

The annual survey data are classified into 23 different sectors based on International Standard Industrial Classification (ISIC) Revision 3. For the present analysis, Armundito and Kaneko [32] have developed a cleaned panel dataset to address data quality problems. First removing zero and missing values of particular variables and then applying several consecutive steps including statistical modeling, coefficient of variant approaches, and data balancing, a large number of observations have been removed. As a result, four periods of cleaned and balanced panel datasets are obtained: 1990-1995, 1998-2000, 20032006, and 2008-2010. The number of observations compared to the initial raw data has shrunk to approximately $4 \%$ in the final result. Considering the number of firms for each sector, only sectors that consist of more than 15 firms are selected for further analysis. Therefore, only 18 out of the 23 sectors are employed for the analysis. To avoid price changes over time, GDP deflators are applied to convert these series of datasets into constant prices based on the year 2000. Additionally, to convert the currency from Indonesia's rupiah to the US dollar, the currency rate for the year 2000 is applied. 
Data on quantities of inputs, desirable outputs, and undesirable outputs are required to estimate productivity change over time using the Malmquist productivity index and the Malmquist-Luenberger productivity index. All firms are assumed to share the same production processes, characterized by the production of one desirable output and one undesirable output. Value added to manufacturing production and $\mathrm{CO}_{2}$ emissions are considered to be the proxies for desirable $(y)$ and undesirable $(b)$ outputs, whereas capital ( $x 1)$, labor wages $(x 2)$, and raw materials $(x 3)$ are considered as inputs. The value added $v$ is measured as the difference between the total sales revenue of a firm and the total cost of components, materials, and services in millions of US dollars. Capital $k$ is measured by the replacement value of fixed assets in thousands of US dollars. Labor wage $l$ is measured as the total salary and other incentives for all workers, including production workers and other workers, in thousands of US dollars. Raw material $m$ is measured as the total materials used to produce a unit of output in thousands of US dollars. Finally, both direct and indirect $\mathrm{CO}_{2}$ emissions are measured as the most common type of gas emitted from the burning of fossil fuels used in manufacturing firms in tons $\mathrm{CO}_{2}$ equivalent. Direct and indirect $\mathrm{CO}_{2}$ emissions are calculated from fuel combustion in the manufacturing sector based on the Intergovernmental Panel on Climate Change (IPCC) guidelines [33]. Further, Indonesia's currency rate has devalued since 1998 and a high inflation rate occurred in 1998, resulting in a monetary value for some variables in periods 3 and 4 that are smaller than the monetary value in periods 1 and 2 .

To measure the determinant of environmental productivity, three variables are included: the average domestic fuel price, the average electricity price, and energy dependency. The average domestic fuel price in constant prices (US dollars/TOE) is obtained as the ratio of total energy expenditure to total energy consumption. The average electricity price in constant prices (US dollars/TOE) is the ratio of total electricity expenditure to total energy consumption. Energy dependency (\%) is defined as the ratio of total energy expenditures (US dollars) to total intermediate input expenditures (US dollars).

The descriptive statistics for the variables are presented in Table 4.

\section{Results and discussion}

Under two assumptions of the disposability of undesirable outputs, the Malmquist productivity index is applied to estimate TFP without $\mathrm{CO}_{2}$ emissions over time and the Malmquist-Luenberger productivity index is employed to measure TFP with $\mathrm{CO}_{2}$ emissions over time. A summary of the estimation results on an average annual basis for period 1 from 1990 to 1995 is presented in Table 5. Of the measurements without $\mathrm{CO}_{2}$ emissions, the average productivity index score is 1.0014 , implying that the annual TFP without $\mathrm{CO}_{2}$ emissions over time for the manufacturing sector increases by $0.14 \%$ over the entire period. This annual TFP score is obtained as the weighted mean of all sectors' TFP scores because the number of firms is different for each sector. On average, this growth is due to an increase in efficiency change of $0.97 \%$ and a decrease in technological progress of $0.01 \%$. Based on the sector-by-sector analysis, considerable variation across sectors is observed. The sector that exhibits the highest productivity growth is motor vehicles, trailers, and semi-trailers (1.64\%), and the sector with the 
Table 4 Descriptive statistics of the variables used for all periods

\begin{tabular}{|c|c|c|c|c|}
\hline Variable code & Description & Unit & Mean & $\begin{array}{l}\text { Standard } \\
\text { deviation }\end{array}$ \\
\hline \multicolumn{5}{|c|}{ Period of 1990-1995 } \\
\hline k & Capital & Thousands of US dollar & 450.80 & 1691.45 \\
\hline 1 & Labor wage & Thousands of US dollar & 263.94 & 873.13 \\
\hline$m$ & Raw material & Thousands of US dollar & 607.63 & 2774.68 \\
\hline$v$ & Value added & Thousands of US dollar & 317.11 & 1370.26 \\
\hline $\mathrm{CO}_{2}$ & $\mathrm{CO}_{2}$ emissions & Tons $\mathrm{CO}_{2}$ equivalent & 584.88 & 2113.26 \\
\hline Y & $\begin{array}{l}\text { Environmental productivity } \\
\text { change over time }\end{array}$ & $\%$ & 1.15 & 2.72 \\
\hline Energydep & Energy dependency & $\%$ & 2 & 0.02 \\
\hline Fuelprice & Fuel price & US dollar/tons of oil eq. & 40.88 & 16.17 \\
\hline Elecprice & Electricity price & US dollar/tons of oil eq. & 152.99 & 82.46 \\
\hline \multicolumn{5}{|c|}{ No. of observations 9336} \\
\hline \multicolumn{5}{|c|}{ Period of 1998-2000 } \\
\hline k & Capital & Thousands of US dollar & 352.88 & 1530.00 \\
\hline 1 & Labor wage & Thousands of US dollar & 86.35 & 404.82 \\
\hline$m$ & Raw material & Thousands of US dollar & 596.34 & 3302.94 \\
\hline$v$ & Value added & Thousands of US dollar & 381.29 & 3211.77 \\
\hline $\mathrm{CO}_{2}$ & $\mathrm{CO}_{2}$ emissions & Tons $\mathrm{CO}_{2}$ equivalent & 666.49 & 2229.87 \\
\hline Y & $\begin{array}{l}\text { Environmental productivity } \\
\text { change over time }\end{array}$ & $\%$ & 1.10 & 1.10 \\
\hline Energydep & Energy dependency & $\%$ & 5 & 0.06 \\
\hline Fuelprice & Fuel price & US dollar/tons of oil eq. & 67.47 & 25.99 \\
\hline Elecprice & Electricity price & US dollar/tons of oil eq. & 194.83 & 97.90 \\
\hline \multicolumn{5}{|c|}{ No. of observations 4668} \\
\hline \multicolumn{5}{|c|}{ Period of 2003-2006 } \\
\hline k & Capital & Thousands of US dollar & 127.14 & 408.26 \\
\hline 1 & Labor wage & Thousands of US dollar & 86.27 & 216.78 \\
\hline$m$ & Raw material & Thousands of US dollar & 236.26 & 1489.42 \\
\hline$v$ & Value added & Thousands of US dollar & 119.65 & 583.46 \\
\hline $\mathrm{CO}_{2}$ & $\mathrm{CO}_{2}$ emissions & Tons $\mathrm{CO}_{2}$ equivalent & 282.02 & 1434.19 \\
\hline Y & $\begin{array}{l}\text { Environmental productivity } \\
\text { change over time }\end{array}$ & $\%$ & 1.154 & 1.04 \\
\hline Energydep & Energy dependency & $\%$ & 8 & 0.08 \\
\hline Fuelprice & Fuel price & US dollar/tons of oil eq. & 215.66 & 104.18 \\
\hline Elecprice & Electricity price & US dollar/tons of oil eq. & 696.57 & 431.92 \\
\hline \multicolumn{5}{|c|}{ No. of observations 3296} \\
\hline \multicolumn{5}{|c|}{ Period of 2008-2010 } \\
\hline k & Capital & Thousands of US dollar & 120.00 & 441.86 \\
\hline 1 & Labor wage & Thousands of US dollar & 84.76 & 253.55 \\
\hline$m$ & Raw material & Thousands of US dollar & 298.67 & 1924.40 \\
\hline$v$ & Value added & Thousands of US dollar & 119.50 & 385.95 \\
\hline $\mathrm{CO}_{2}$ & $\mathrm{CO}_{2}$ emissions & Tons $\mathrm{CO}_{2}$ equivalent & 243.63 & 1054.26 \\
\hline Y & $\begin{array}{l}\text { Environmental productivity } \\
\text { change over time }\end{array}$ & $\%$ & 1.08 & 0.56 \\
\hline
\end{tabular}


Table 4 Descriptive statistics of the variables used for all periods (Continued)

\begin{tabular}{lllll}
\hline Energydep & Energy dependency & $\%$ & 13 & 0.12 \\
Fuelprice & Fuel price & US dollar/tons of oil eq. & 518.55 & 186.15 \\
Elecprice & Electricity price & US dollar/tons of oil eq. & 1007.62 & 660.44 \\
No. of observations & 2472 & & & \\
\hline
\end{tabular}

lowest growth is fabricated metal products and equipment $(-0.07 \%)$. Furthermore, for the measurement with $\mathrm{CO}_{2}$ emissions, the weighted mean of the TFP scores is 1.0198, indicating that the annual TFP with $\mathrm{CO}_{2}$ emissions over time for the manufacturing sector increases by $1.98 \%$ over the entire period. This increasing growth is considerably higher than the growth of TFP without $\mathrm{CO}_{2}$ emissions. This average TFP with $\mathrm{CO}_{2}$ emissions over time is due to an increase in efficiency change $(7.69 \%)$ and technological progress $(5.87 \%)$. The sector that shows the highest productivity growth is other non-metallic mineral products $(11.1 \%)$ and the sector with the lowest growth is chemicals and chemical products $(-2.7 \%)$. At the same time, the average TFP environment score for period 1 is 1.0184, suggesting that environmental productivity increases by $1.84 \%$ annually.

The productivity measurement for period 2 from 1998 to 2000 is presented in Table 6 . The average of the weighted means productivity index score is 0.9933 , indicating that the annual TFP without $\mathrm{CO}_{2}$ emissions over time for the manufacturing sector dropped by $0.67 \%$ over the entire period. This change is triggered by an increase in efficiency change $(1.58 \%)$ and a decrease in technological progress $(1.94 \%)$. Based on the sector-

Table 5 Average annual changes in productivity growth and its components for period 1

\begin{tabular}{|c|c|c|c|c|c|c|c|}
\hline \multirow[t]{2}{*}{ Sector } & \multicolumn{3}{|c|}{$\begin{array}{l}\text { TFP growth without } \mathrm{CO}_{2} \\
\text { emissions }\end{array}$} & \multicolumn{3}{|c|}{$\begin{array}{l}\text { TFP growth with } \mathrm{CO}_{2} \\
\text { emissions }\end{array}$} & \multirow[t]{2}{*}{$\begin{array}{l}\text { TFP } \\
\text { environment }\end{array}$} \\
\hline & $\mathrm{M}$ & $\mathrm{EFFCH}$ & $\mathrm{TECH}$ & $\mathrm{ML}$ & $\mathrm{EFFCH}$ & TECH & \\
\hline Food products and beverages & 1.0041 & 0.9990 & 1.0080 & 1.0303 & 1.1903 & 1.5534 & 1.0261 \\
\hline Tobacco & 1.0102 & 1.0431 & 0.9722 & 1.0199 & 1.1650 & 0.9346 & 1.0096 \\
\hline Textiles & 1.0073 & 1.0259 & 0.9902 & 1.0052 & 1.1220 & 1.0507 & 0.9980 \\
\hline Wearing apparel & 0.9985 & 0.9886 & 1.0115 & 1.0174 & 1.0305 & 1.0115 & 1.0189 \\
\hline Tanning and dressing of leather & 0.9907 & 1.0465 & 0.9520 & 0.9402 & 1.1152 & 0.8797 & 0.9491 \\
\hline Wood and products of wood and plaiting & 1.0027 & 1.0118 & 0.9915 & 0.9783 & 1.0507 & 0.9713 & 0.9757 \\
\hline Paper and paper products & 1.0094 & 1.0205 & 0.9947 & 0.9915 & 1.0964 & 0.9463 & 0.9823 \\
\hline Publishing, printing, and reproduction & 0.9943 & 0.9931 & 1.0020 & 1.0154 & 1.1494 & 0.9776 & 1.0212 \\
\hline Chemicals and chemical products & 1.0053 & 0.9982 & 1.0106 & 0.9730 & 0.9372 & 1.1142 & 0.9679 \\
\hline Rubber and plastics products & 1.0050 & 0.9999 & 1.0099 & 0.9797 & 1.0146 & 1.0938 & 0.9748 \\
\hline Others non-metallic mineral products & 0.9916 & 1.0070 & 0.9871 & 1.1110 & 1.1159 & 1.0953 & 1.1205 \\
\hline Basic metals & 1.0318 & 1.0346 & 0.9980 & 1.0165 & 1.0182 & 1.0433 & 0.9852 \\
\hline Fabricated metal products and equipment & 0.9903 & 1.0041 & 1.0031 & 0.9924 & 1.0795 & 1.0858 & 1.0021 \\
\hline Machinery and equipment & 1.0017 & 1.0360 & 0.9739 & 1.0327 & 1.2134 & 0.9832 & 1.0310 \\
\hline Electrical machinery and apparatus & 1.0070 & 0.9630 & 1.0548 & 1.0065 & 0.9444 & 1.1185 & 0.9995 \\
\hline Motor vehicle, trailers, and semi-trailers & 1.0164 & 1.0005 & 1.0195 & 1.0105 & 0.9965 & 1.0517 & 0.9943 \\
\hline Other transport equipment & 1.0101 & 1.0124 & 1.0113 & 1.0619 & 1.1018 & 1.1400 & 1.0513 \\
\hline Furniture and manufacturing & 0.9923 & 0.9898 & 1.0074 & 0.9971 & 1.0436 & 1.0061 & 1.0049 \\
\hline Weighted mean & 1.0014 & 1.0097 & 0.9999 & 1.0198 & 1.0769 & 1.0587 & 1.0184 \\
\hline
\end{tabular}

TFP total factor productivity 
Table 6 Average annual changes in productivity growth and its components for period 2

\begin{tabular}{|c|c|c|c|c|c|c|c|}
\hline \multirow[t]{2}{*}{ Sector } & \multicolumn{3}{|c|}{$\begin{array}{l}\text { TFP growth without } \mathrm{CO}_{2} \\
\text { emissions }\end{array}$} & \multicolumn{3}{|c|}{$\begin{array}{l}\text { TFP growth with } \mathrm{CO}_{2} \\
\text { emissions }\end{array}$} & \multirow[t]{2}{*}{$\begin{array}{l}\text { TFP } \\
\text { environment }\end{array}$} \\
\hline & M & EFFCH & $\mathrm{TECH}$ & $\mathrm{ML}$ & $\mathrm{EFFCH}$ & $\mathrm{TECH}$ & \\
\hline Food products and beverages & 0.9933 & 1.0163 & 0.9774 & 1.0603 & 1.2147 & 0.8838 & 1.0674 \\
\hline Tobacco & 0.9979 & 1.0054 & 0.9923 & 1.0129 & 1.0670 & 0.9754 & 1.0150 \\
\hline Textiles & 1.0049 & 1.0105 & 0.9965 & 1.0448 & 1.1088 & 0.9967 & 1.0397 \\
\hline Wearing apparel & 0.9985 & 1.0236 & 0.9797 & 1.1001 & 1.2215 & 0.9992 & 1.1017 \\
\hline Tanning and dressing of leather & 1.0002 & 0.9941 & 1.0108 & 1.0559 & 0.9083 & 1.4272 & 1.0557 \\
\hline Wood and products of wood and plaiting & 0.9953 & 0.9746 & 1.0243 & 0.9778 & 0.7279 & 1.5209 & 0.9824 \\
\hline Paper and paper products & 0.9696 & 0.9944 & 0.9825 & 0.9286 & 0.8073 & 1.2034 & 0.9577 \\
\hline Publishing, printing, and reproduction & 0.9754 & 1.0192 & 0.9641 & 0.9674 & 0.9221 & 1.0727 & 0.9918 \\
\hline Chemicals and chemical products & 0.9947 & 1.0293 & 0.9703 & 1.1403 & 1.0646 & 1.0855 & 1.1464 \\
\hline Rubber and plastics products & 0.9941 & 1.0109 & 0.9875 & 1.2047 & 1.1510 & 1.0871 & 1.2118 \\
\hline Others non-metallic mineral products & 0.9952 & 1.0039 & 0.9933 & 1.1013 & 1.1688 & 0.9872 & 1.1066 \\
\hline Basic metals & 0.9939 & 1.0757 & 0.9339 & 1.0869 & 1.4516 & 0.8474 & 1.0936 \\
\hline Fabricated metal products and equipment & 0.9825 & 1.1075 & 0.8949 & 1.0471 & 1.5578 & 0.7498 & 1.0657 \\
\hline Machinery and equipment & 0.9774 & 1.0396 & 0.9440 & 0.9954 & 1.1737 & 0.9150 & 1.0184 \\
\hline Electrical machinery and apparatus & 0.9795 & 0.9774 & 1.0043 & 1.0224 & 0.9711 & 1.0791 & 1.0439 \\
\hline Motor vehicle, trailers, and semi-trailers & 0.9903 & 0.9726 & 1.0199 & 1.0516 & 0.9376 & 1.1286 & 1.0619 \\
\hline Other transport equipment & 1.0010 & 1.0067 & 0.9972 & 1.0212 & 0.9297 & 1.1017 & 1.0202 \\
\hline Furniture and manufacturing & 0.9978 & 1.0220 & 0.9784 & 1.0091 & 1.0678 & 0.9622 & 1.0113 \\
\hline Weighted mean & 0.9933 & 1.0158 & 0.9806 & 1.0652 & 1.0806 & 1.0568 & 1.0724 \\
\hline
\end{tabular}

by-sector analysis, the sector that shows the highest productivity growth is textiles $(0.49 \%)$, and the sector with the lowest productivity growth is paper and paper products $(-3.04 \%)$. For the measurement with $\mathrm{CO}_{2}$ emissions, the weighted mean of the TFP score is 1.0652 , implying that the annual TFP with $\mathrm{CO}_{2}$ emissions over time increases by $6.52 \%$ over the entire period. This increasing growth is significantly higher than the growth of TFP without $\mathrm{CO}_{2}$ emissions. This remarkable growth is caused by an increase in efficiency $(8.06 \%)$ and technological progress $(5.68 \%)$. The sector that demonstrates the best-performance is rubber and plastics products, with productivity growth of $20.47 \%$, and the sector with the worst performance is paper and paper products, with a decrease in productivity of $2.22 \%$. Meanwhile, the TFP environment score for period 2 is 1.0724 , suggesting that environmental productivity increases by $7.24 \%$ annually.

The productivity measurement for period 3 from 2003 to 2006 is presented in Table 7, and the average TFP without $\mathrm{CO}_{2}$ emissions score is 1.0050 . The average TFP score indicates that the annual TFP without $\mathrm{CO}_{2}$ emissions increases by $0.50 \%$ over the entire period. Increases in the efficiency change $(0.49 \%)$ and technological progress $(1.55 \%)$ are the sources of this TFP growth. Tobacco is the sector that shows the highest productivity growth (4.45\%), whereas textiles sector exhibits the lowest productivity growth (1.71\%). At the same time, the weighted mean score of TFP with $\mathrm{CO}_{2}$ emissions is 1.0036, implying that the annual TFP with $\mathrm{CO}_{2}$ emissions over time increased by $0.36 \%$ over the entire period. The increase in efficiency change $(7.18 \%)$ and technological progress $(7.57 \%)$ are the engines of this TFP growth. The sector that shows the 
Table 7 Average annual changes in productivity growth and its components for period 3

\begin{tabular}{|c|c|c|c|c|c|c|c|}
\hline \multirow[t]{2}{*}{ Sector } & \multicolumn{3}{|c|}{$\begin{array}{l}\text { TFP growth without } \mathrm{CO}_{2} \\
\text { emissions }\end{array}$} & \multicolumn{3}{|c|}{$\begin{array}{l}\text { TFP growth with } \mathrm{CO}_{2} \\
\text { emissions }\end{array}$} & \multirow[t]{2}{*}{$\begin{array}{l}\text { TFP } \\
\text { environment }\end{array}$} \\
\hline & M & EFFCH & $\mathrm{TECH}$ & $\mathrm{ML}$ & $\mathrm{EFFCH}$ & $\mathrm{TECH}$ & \\
\hline Food products and beverages & 0.9991 & 0.9724 & 1.0286 & 1.0100 & 0.9201 & 1.1757 & 1.0109 \\
\hline Tobacco & 1.0445 & 1.0883 & 0.9698 & 1.1102 & 1.7478 & 0.8695 & 1.0629 \\
\hline Textiles & 0.9829 & 0.9917 & 0.9940 & 0.9698 & 0.9885 & 1.0951 & 0.9867 \\
\hline Wearing apparel & 0.9956 & 1.0288 & 0.9701 & 1.0064 & 1.3685 & 0.9862 & 1.0109 \\
\hline Tanning and dressing of leather & 1.0438 & 1.0262 & 1.0169 & 1.0460 & 1.0516 & 1.0048 & 1.0021 \\
\hline Wood and products of wood and plaiting & 1.0098 & 0.9497 & 1.0813 & 1.1137 & 1.0586 & 1.2980 & 1.1029 \\
\hline Paper and paper products & 1.0042 & 1.0073 & 0.9967 & 1.0074 & 1.0321 & 0.9822 & 1.0032 \\
\hline Publishing, printing, and reproduction & 1.0042 & 1.0073 & 0.9967 & 1.0074 & 1.0321 & 0.9822 & 1.0032 \\
\hline Chemicals and chemical products & 0.9906 & 0.9726 & 1.0226 & 0.8033 & 0.7201 & 1.2626 & 0.8109 \\
\hline Rubber and plastics products & 1.0140 & 1.0428 & 0.9764 & 0.9827 & 1.4561 & 0.6780 & 0.9691 \\
\hline Others non-metallic mineral products & 1.0001 & 0.9653 & 1.0385 & 0.9714 & 0.8091 & 1.2040 & 0.9712 \\
\hline Basic metals & 1.0370 & 0.9432 & 1.1123 & 1.0719 & 0.9100 & 1.2206 & 1.0336 \\
\hline Fabricated metal products and equipment & 1.0345 & 0.9963 & 1.0450 & 0.9685 & 0.8542 & 1.2306 & 0.9362 \\
\hline Machinery and equipment & 1.0229 & 0.9871 & 1.0360 & 1.0435 & 0.9220 & 1.1443 & 1.0201 \\
\hline Electrical machinery and apparatus & 1.0443 & 1.0774 & 0.9854 & 1.0548 & 1.2721 & 0.9612 & 1.0100 \\
\hline Motor vehicle, trailers, and semi-trailers & 1.0280 & 1.0108 & 1.0176 & 1.0367 & 1.0575 & 1.0440 & 1.0084 \\
\hline Other transport equipment & 1.0055 & 1.0374 & 0.9726 & 1.0418 & 1.0333 & 1.0084 & 1.0361 \\
\hline Furniture and manufacturing & 1.0003 & 0.9836 & 1.0185 & 1.0160 & 1.0583 & 1.2153 & 1.0157 \\
\hline Weighted mean & 1.0050 & 1.0049 & 1.0155 & 1.0036 & 1.0718 & 1.0757 & 0.9986 \\
\hline
\end{tabular}

highest productivity growth is wood and products of wood and plaiting (11.37\%), and the sector with the lowest growth is chemicals and chemical products $(-19.67 \%)$. On average, the TFP environment score for period 3 is 0.9986 , suggested that environmental productivity decreased by $0.14 \%$ annually.

The productivity measurement for period 4 from 2008 to 2010 is shown in Table 8 . The average of the weighted means productivity index score is 1.0311, implying that the annual TFP without $\mathrm{CO}_{2}$ emissions over time increases by $3.11 \%$ over the entire period. This growth is due to an increase in efficiency change of $0.33 \%$ and in technological progress of $3.65 \%$. The sector with the highest productivity growth is electrical machinery and apparatus. (6.72\%), and the sector with the lowest growth is tanning and dressing of leather $(0.06 \%)$. Furthermore, the measurement of TFP with $\mathrm{CO}_{2}$ emissions results in a weighted mean TFP score of 1.0523, suggesting that the annual TFP with $\mathrm{CO}_{2}$ emissions increases by $5.23 \%$ over the entire period. The growth is generated by the increase in efficiency change $(1.77 \%)$ and technological progress $(11.83 \%)$. The sector that shows the highest productivity growth is basic metals $(14.73 \%)$ and the sector that presents the lowest productivity growth is tobacco $(0.89 \%)$. The TFP environment score for period 4 is 1.0206 , implying that environmental productivity increases by $2.06 \%$ annually.

The comparisons between the periods enable an evaluation of the impact of implemented policies or economic circumstances as contextual background of this analysis on manufacturing performance. The export-led industrialization policy implemented in period 1 not only resulted in the highest level for the GDP growth rate and the growth 
Table 8 Average annual changes in productivity growth and its components for period 4

\begin{tabular}{|c|c|c|c|c|c|c|c|}
\hline \multirow[t]{2}{*}{ Sector } & \multicolumn{3}{|c|}{$\begin{array}{l}\text { TFP growth without } \mathrm{CO}_{2} \\
\text { emissions }\end{array}$} & \multicolumn{3}{|c|}{$\begin{array}{l}\text { TFP growth with } \mathrm{CO}_{2} \\
\text { emissions }\end{array}$} & \multirow[t]{2}{*}{$\begin{array}{l}\text { TFP } \\
\text { environment }\end{array}$} \\
\hline & M & EFFCH & $\mathrm{TECH}$ & $\mathrm{ML}$ & EFFCH & TECH & \\
\hline Food products and beverages & 1.0167 & 0.9672 & 1.0524 & 1.0450 & 1.0338 & 1.1743 & 1.0279 \\
\hline Tobacco & 1.0178 & 0.9742 & 1.0454 & 0.9911 & 0.9483 & 1.1034 & 0.9738 \\
\hline Textiles & 1.0209 & 0.9432 & 1.0853 & 1.0482 & 0.8590 & 1.2842 & 1.0267 \\
\hline Wearing apparel & 1.0257 & 1.0027 & 1.0283 & 1.0506 & 1.0228 & 1.0659 & 1.0243 \\
\hline Tanning and dressing of leather & 1.0006 & 0.9825 & 1.0198 & 1.0433 & 1.0420 & 1.0203 & 1.0426 \\
\hline Wood and products of wood and plaiting & 1.0106 & 1.0217 & 0.9903 & 1.0437 & 1.2793 & 0.8615 & 1.0327 \\
\hline Paper and paper products & 1.0302 & 0.9352 & 1.1086 & 1.1013 & 0.9327 & 1.2866 & 1.0690 \\
\hline Publishing, printing, and reproduction & 1.0368 & 0.9064 & 1.1480 & 1.1205 & 0.8171 & 1.4283 & 1.0807 \\
\hline Chemicals and chemical products & 1.0622 & 1.0002 & 1.0675 & 1.0875 & 0.9524 & 1.1803 & 1.0238 \\
\hline Rubber and plastics products & 1.0408 & 1.0099 & 1.0370 & 1.0543 & 1.0127 & 1.0979 & 1.0130 \\
\hline Others non-metallic mineral products & 1.0345 & 1.0613 & 0.9794 & 1.0499 & 1.1142 & 0.9681 & 1.0148 \\
\hline Basic metals & 1.0333 & 1.0542 & 0.9798 & 1.1473 & 1.0788 & 1.0463 & 1.1103 \\
\hline Fabricated metal products and equipment & 1.0277 & 0.9560 & 1.0801 & 1.0571 & 0.7765 & 1.4569 & 1.0286 \\
\hline Machinery and equipment & 1.0378 & 1.0756 & 0.9841 & 1.0484 & 1.1844 & 1.0512 & 1.0102 \\
\hline Electrical machinery and apparatus. & 1.0672 & 1.0750 & 0.9991 & 1.0582 & 1.0682 & 1.0525 & 0.9916 \\
\hline Motor vehicle, trailers, and semi-trailers & 1.0475 & 1.0374 & 1.0121 & 1.0634 & 1.0838 & 1.0027 & 1.0152 \\
\hline Other transport equipment & 1.0349 & 1.0461 & 0.9904 & 1.0565 & 1.1154 & 0.9563 & 1.0209 \\
\hline Furniture and manufacturing & 1.0583 & 1.0111 & 1.0492 & 1.0627 & 0.9977 & 1.0929 & 1.0042 \\
\hline Weighted mean & 1.0311 & 1.0033 & 1.0365 & 1.0523 & 1.0177 & 1.1183 & 1.0206 \\
\hline
\end{tabular}

rate of the manufacturing sector but also positively influenced the growth of TFP with $\mathrm{CO}_{2}$ emissions. In this period, the growth of TFP with $\mathrm{CO}_{2}$ emissions over time was tenfold that of the growth of the TFP without $\mathrm{CO}_{2}$ emissions. The TFP environment over time in period 1 also shows positive moderate growth.

Considering period 2 to represent the immediate post-economic crisis period and the beginning of democratic reforms, the growth of TFP with $\mathrm{CO}_{2}$ emissions over time was the highest. During the same period, the decline of average GDP growth and the growth rate for the manufacturing sector from the previous period resulted in negative growth for TFP without $\mathrm{CO}_{2}$ emissions. Meanwhile, the TFP environment over time in period 1 also exhibited the highest growth, even surpassing the TFP with $\mathrm{CO}_{2}$ emissions over time. The remarkable achievement of environmental measures in this period is consistent with the notable increase in the share of manufactured exports to merchandise exports and the share of high-technology exports to manufactured exports.

Period 3 is regarded as a period of politically significant transitional moments, and the government of Indonesia began to remove subsidies for oil commodities. During period 3, the growth of TFP with $\mathrm{CO}_{2}$ emissions over time dropped sharply compared with the previous period. Several sectors, particularly for the high energy-intensive sectors, might be negatively affected by the increase in prices of oil commodities. The TFP with $\mathrm{CO}_{2}$ emissions over time of the high energy-intensive sectors: food and beverages; textiles and its related industry; chemicals and chemical product; rubber and plastics product; others non-metallic mineral product; and fabricated metal product and equipment sectors present considerable decline in this period. Only basic metals sector that 
shows insignificant decrease. The effort in reducing $\mathrm{CO}_{2}$ emissions seems to have further pressures due to the increase in prices of oil commodities. A similarly worsened performance was also experienced by the TFP environment over time as the growth dramatically declined to reach a negative level. In contrast, TFP without $\mathrm{CO}_{2}$ emissions over time indicated positive growth. Almost all of the sectors show a notable increase of this TFP, except for textiles and wearing apparel sectors. Despite the increase in energy costs, the growth rate in the manufacturing sector increased from the previous period.

Furthermore in period 4, when the global financial crisis took place, the growth of all TFP measurements over time demonstrated a remarkable increase compared with period 3. Compared to the previous three periods, the growth of TFP without $\mathrm{CO}_{2}$ emissions over time was the highest in this period even though the level of growth was still lower than that for TFP without $\mathrm{CO}_{2}$ emissions over time. At the same time, the TFP environment over time also grew at a level equal to that in period 1. The economic and political policies implemented by the government during this period were able to address the adverse effects of the global financial crisis in Indonesia, particularly in the manufacturing sector.

Overall, it is observed that TFP with $\mathrm{CO}_{2}$ emissions over time has grown faster than TFP without $\mathrm{CO}_{2}$ emissions for periods 1,2 , and 4 . The faster growth of TFP with $\mathrm{CO}_{2}$ emissions over time is consistent with Domazlicky and Weber [15], Färe et al. [14], and Kumar [18], who suggested that when accounting for changes in pollution as an undesirable output, the average productivity growth is higher than the growth when ignoring pollution. TFP with $\mathrm{CO}_{2}$ emissions over time lower than TFP without $\mathrm{CO}_{2}$ emissions was observed in period 3. However, in general, the manufacturing sector showed the best performance in period 4 , characterized by a positive growth level for all TFP measures, including a positive growth level of its components: efficiency change and technological progress. Efficiency change is the source of productivity growth in periods 1 and 2, whereas technical progress is the basis of productivity growth in periods 3 and 4. In particular, three outstanding sectors have been noted as the bestperforming sectors with the highest productivity growth for all periods: motor vehicles, trailers, and semi-trailers; electrical machinery and apparatus; and basic metals. The best-performing sectors might be interpreted as a positive response to changes in the prices of oil commodities by maintaining the positive growth of TFP with $\mathrm{CO}_{2}$ emissions over time during all periods.

Because there is no empirical evidence confirming that the increase in energy costs might directly affect manufacturing productivity, the relationship of energy factors and environmental productivity is analyzed. Estimation results evaluating the influence of energy factors on environmental productivity changes over time in Indonesia's manufacturing sector are presented in Table 9. Fuel price is statistically significant during 2003-2006 and shows a negative relationship to changes in environmental productivity. When energy is still subsidized during the 1990-1994 and 1998-1999 periods, the energy dependency of the manufacturing sector is relatively small. Fuel and electricity prices do not play a significant role in enhancing environmental productivity. The energy policies implemented after 2003 aimed to remove subsidies for oil commodities and caused fuel and electricity prices to increase. As energy dependency also increased, energy prices started to negatively influence environmental 
Table 9 Factors associated with changes in environmental productivity

\begin{tabular}{lllll}
\hline Independent variables & \multicolumn{3}{l}{ Periods } & \\
\cline { 2 - 5 } & $1990-1994$ & $1998-2000$ & $2003-2006$ & $2008-2010$ \\
\hline Energydep & -0.1222 & -0.3973 & -0.3792 & -0.1314 \\
Fuelprice & 0.0011 & -0.0011 & $-0.0005^{\mathrm{b}}$ & -0.0000 \\
Elecprice & -0.0004 & -0.0000 & -0.0000 & $-0.0000^{\mathrm{c}}$ \\
dsec1 & 0.1256 & $-0.1876^{\mathrm{a}}$ & -0.1629 & $-0.0857^{\mathrm{c}}$ \\
dsec2 & -0.0012 & -0.0040 & -0.1773 & $-0.1253^{\mathrm{b}}$ \\
dsec3 & -0.1320 & $-0.1299^{\mathrm{c}}$ & -0.0391 & -0.0349 \\
dsec4 & $-0.2077^{\mathrm{c}}$ & -0.0842 & $-0.4547^{\mathrm{a}}$ & -0.0169 \\
dsec5 & -0.0154 & -0.0428 & -0.1086 & -0.0408 \\
Constant & 1.0805 & 1.0757 & 1.0976 & 1.2024 \\
Number of observations & 7795 & 3118 & 2451 & 1634 \\
\hline
\end{tabular}

${ }^{\mathrm{a}} \mathrm{A}$ variable is significant at a $1 \%$ level of significance

${ }^{\mathrm{b}} \mathrm{A}$ variable is significant at a $5 \%$ level of significance

${ }^{\mathrm{C}} \mathrm{A}$ variable is significant at a $10 \%$ level of significance

productivity improvements. Hence, the change of the environmental component in productivity measurements, in terms of the level of $\mathrm{CO}_{2}$ emission reduction, is associated with adjusted energy prices.

In addition, the coefficients of the sectoral dummy variables are positive and statistically significant for particular periods. As the metal and mineral group sector is the basis of the sectoral dummy, the chemical, rubber, and plastic group has a greater effect, at a $10 \%$ significance level, in period 1 . In period 2, the food, beverage, and tobacco group has a greater effect at a $1 \%$ significance level and the wood, paper, printing, and furniture group has a greater effect at a $10 \%$ significance level than the metal and mineral group. In period 3, the chemical, rubber, and plastic group has a greater effect at $1 \%$ significance level than the metal and mineral group, whereas in period 4, the food, beverage, and tobacco group has a greater effect at a $10 \%$ significance level and the textile and leather group has a greater effect at a $5 \%$ significance level than the metal and mineral group.

\section{Conclusions}

This paper provides a baseline analysis of TFP growth over time with and without considering $\mathrm{CO}_{2}$ emissions from 1990 to 2000. Considering the current data problems and missing key variable data, cleaned and balanced panel datasets are constructed for only four periods: 1990-1995, 1998-2000, 2003-2006, and 2008-2010. The four periods of cleaned and balanced panel datasets enable an evaluation of the impact of implemented policies or economic circumstances during each period. An assumption is made that undesirable outputs are weakly disposable because Indonesia has not implemented carbon regulations. The Malmquist productivity index is employed to estimate TFP without $\mathrm{CO}_{2}$ emissions over time, and the Malmquist-Luenberger productivity index is applied to estimate TFP with $\mathrm{CO}_{2}$ emissions over time. The influence of energy factors on environmental productivity changes over time is also investigated.

The main findings of this paper can be summarized as follows. First, on average, TFP with $\mathrm{CO}_{2}$ emissions over time has grown faster than TFP without $\mathrm{CO}_{2}$ emissions, 
particularly for periods 1,2 , and 4 . Second, efficiency change is the source of productivity growth in periods 1 and 2, whereas technical progress is the basis of productivity growth in periods 3 and 4 . Third, climate change mitigation policy might lead to the increase of additional burden for the high energy-intensive sectors. And the bestperforming sectors, based on their ability to maintain the positive growth of TFP with $\mathrm{CO}_{2}$ emissions over time in response to changes in the prices of oil commodities during all periods are shown by (i) motor vehicle, trailers, and semi-trailers, (ii) electrical machinery and apparatus, and (iii) basic metals. Fourth, the change in environmental productivity is significantly associated with adjusted energy prices.

Several constructive policy designs can be derived from these findings. The results suggest that $\mathrm{CO}_{2}$ emissions as undesirable outputs can be considered when measuring the manufacturing sector's productivity growth as a response to climate change mitigation policy. Valuable lessons learned from the best-performing manufacturing sectors can be applied to other manufacturing sectors responding to changes in the prices of oil commodities. At the same time, technological improvement is expected to be a major concern for manufacturing firms' long-term strategic planning after changes in the prices of oil commodities.

Competing interests

The authors declare that they have no competing interests.

\section{Acknowledgements}

The authors thank two anonymous referees for their very helpful and constructive comments on an earlier draft of this paper, as well as the financial aid received from the Japan International Cooperation Agency (Project of Capacity Development for Climate Change Strategy in Indonesia). The authors are also grateful to Fuji Xerox Co., Ltd., and the Setsutaro Kobayashi Memorial Fund for additional financial support. The usual disclaimer applies.

Received: 31 May 2015 Accepted: 12 June 2015

Published online: 27 June 2015

\section{References}

1. Global Carbon Project (2014) The Global Carbon Project. http://www.globalcarbonproject.org. Accessed 14 Apr 2015

2. IEA. Energy balances of non-OECD countries 2013. Paris: International Energy Agency; 2013.

3. Goeltom M. Indonesia's financial liberalization: an empirical analysis of 1981-88 panel data. Institute of Southeast Asian Studies, Singapore: ASEAN Economic Research Unit; 1995.

4. Pangestu M. Economic reform, deregulation, and privatization: the Indonesian experience. Jakarta: Centre for Strategic and International Studies; 1996.

5. Timmer MP. Indonesia's ascent on the technology ladder: capital stock and total factor productivity in Indonesian manufacturing, 1975-95. Bull Indones Econ Stud. 1999;35:75-97. doi:10.1080/00074919912331337497.

6. Aswicahyono H, Hill H. "Perspiration" vs "inspiration" in Asian industrialisation: Indonesia before the crisis. J Dev Stud. 2002;38:138-63. doi:10.1080/00220380412331322381.

7. Vial V. New estimates of total factor productivity growth in Indonesian manufacturing. Bull Indones Econ Stud. 2006:42:357-69. doi:10.1080/00074910601053227.

8. Coelli TJ, Rao DSP. Total factor productivity growth in agriculture: a Malmquist index analysis of 93 countries, 1980-2000. Agric Econ. 2005;32:115-34. doi:10.1111/j.0169-5150.2004.00018.x.

9. Färe R, Grosskopf S, Lovell C a K, Pasurka C. Multilateral productivity comparisons when some outputs are undesirable: a nonparametric approach. Rev Econ Stat. 1989;71:90-8. doi:10.2307/1928055.

10. Färe R, Grosskopf S, Tyteca D. An activity analysis model of the environmental performance of firms - application to fossil-fuel-fired electric utilities. Ecol Econ. 1996;18:161-75. doi:10.1016/0921-8009(96)00019-5.

11. Tyteca D. Linear programming models for the measurement of environmental performance of firms - concepts and empirical results. J Product Anal. 1997:8:183-97.

12. Nakano M, Managi S. Waste generations and efficiency measures in Japan. Environ Econ Policy Stud. 2012;14:327-39. doi:10.1007/s10018-012-0038-2.

13. Chung YH, Färe R, Grosskopf S (1997) Productivity and undesirable outputs: a directional distance function approach. J Environ Manage 51:229-240. http://dx.doi.org/10.1006/jema.1997.0146

14. Färe R, Grosskopf S, Pasurka C a. Accounting for air pollution emissions in measures of state manufacturing productivity growth. J Reg Sci. 2001;41:381-409. doi:10.1111/0022-4146.00223.

15. Domazlicky BR, Weber WL. Does environmental protection lead to slower productivity growth in the chemical industry? Environ Resour Econ. 2004;28:301-24. doi:10.1023/B:EARE.0000031056.93333.3a.

16. He F, Zhang Q, Lei J, Fu W, Xu X. Energy efficiency and productivity change of China's iron and steel industry: accounting for undesirable outputs. Energy Policy. 2013;54:204-13. doi:10.1016/j.enpol.2012.11.020. 
17. Piot-Lepetit I, Moing ML. Productivity and environmental regulation: the effect of the nitrates directive in the french pig sector. Environ Resour Econ. 2007:38:433-46. doi:10.1007/s10640-007-9086-7.

18. Kumar S. Environmentally sensitive productivity growth: a global analysis using Malmquist-Luenberger index. Ecol Econ. 2006;56:280-93. doi:10.1016/j.ecolecon.2005.02.004.

19. Oh DH. A global Malmquist-Luenberger productivity index. J Product Anal. 2010;34:183-97. doi:10.1007/s11123010-0178-y.

20. Zhang C, Liu H, Bressers HT a, Buchanan KS. Productivity growth and environmental regulations - accounting for undesirable outputs: analysis of China's thirty provincial regions using the Malmquist-Luenberger index. Ecol Econ. 2011;70:2369-79. doi:10.1016/j.ecolecon.2011.07.019

21. Boyd GA, Tolley G, Pang J. ) Plant level productivity, efficiency, and environmental performance of the container glass industry. Environ Resour Econ. 2002;23:29-43.

22. Heng Y, Lim SH, Chi J. Toxic air pollutants and trucking productivity in the US. Transp Res Part D Transp Environ. 2012;17:309-16. doi:10.1016/j.trd.2012.01.001

23. Krautzberger $L$, Wetzel $H$. Transport and CO2: productivity growth and carbon dioxide emissions in the european commercial transport industry. Environ Resour Econ. 2012:53:435-54. doi:10.1007/s10640-012-9569-z.

24. Managi S, Jena PR. Environmental productivity and Kuznets curve in India. Ecol Econ. 2008;65:432-40. doi:10.1016/j.ecolecon.2007.07.011.

25. Kumar S, Managi S. Environment and productivities in developed and developing countries: the case of carbon dioxide and sulfur dioxide. J Environ Manage. 2010;91:1580-92. doi:10.1016/j.jenvman.2010.03.003.

26. Färe R, Grosskopf S, Lovell C (1994) Production frontiers. Cambridge: Cambridge University Press

27. Mandal S, Madheswaran S. Environmental efficiency of the Indian cement industry: an interstate analysis. Energy Policy. 2010;38:1108-18. doi:10.1016/j.enpol.2009.10.063.

28. Hamilton JD. A neoclassical model of unemployment and the business cycle. J Polit Econ. 1988;96:593. doi:10.1086/261553.

29. Hooker MA. Are oil shocks inflationary? Asymmetric and nonlinear specifications versus changes in regime. J Money Credit Bank. 2002;34:540-61.

30. Hamilton JD (2009) Causes and Consequences of the Oil Shock of 2007-08. National Bureau of Economic Research Cambridge, MA. http://www.nber.org/papers/w15002.pdf

31. Aye GC, Dadam V, Gupta R, Mamba B. Oil price uncertainty and manufacturing production. Energy Econ. 2014:43:41-7. doi:10.1016/j.eneco.2014.02.004.

32. Armundito E, Kaneko S (2014) Note on Data Cleaning and Panel Data Development of Indonesian Manufacturing Survey Data (IDEC DP2 Series No. 4-9). Hiroshima University, Graduate School for International Development and Cooperation (IDEC)

33. Eggleston H, Buendia L, Miwa K, Ngara T, Tanabe K. IPCC guidelines for national greenhouse gas inventories. Hayama, Japan: Institute for Global Environmental Strategies; 2006.

34. Ikhsan-Modjo M (2006) Total factor productivity in Indonesian manufacturing: a stochastic frontier approach. Monash University (ABERU Discussion Paper 28).

Submit your manuscript to a SpringerOpen ${ }^{\circ}$ journal and benefit from:

- Convenient online submission

- Rigorous peer review

- Immediate publication on acceptance

- Open access: articles freely available online

- High visibility within the field

- Retaining the copyright to your article

Submit your next manuscript at $>$ springeropen.com 